\title{
Tropical Archaeology Research Laboratory Comparative Fish Reference Collection: Developing a Resource for Identifying Marine Fish Remains in Archaeological Deposits in Tropical Australasia
}

\author{
Helene Tomkins, Daniel Rosendahl and Sean Ulm
}

Department of Anthropology, Archaeology and Sociology, School of Arts and Social Sciences, James Cook University, PO Box 6811, Cairns QLD 4870, Australia helene.tomkins@my.jcu.edu.au, danrosendahl65@gmail.com, sean.ulm@jcu.edu.au

\begin{abstract}
This paper outlines the methods adopted for creating a fish osteological reference collection for tropical Australasia. This collection currently contains bones from 52 fish representing 35 different species found in the Gulf of Carpentaria, Australia. This developing collection has become a valuable resource for zooarchaeological analyses in the Queensland, Torres Strait and Papua New Guinea tropical coastal zone. Ongoing development of the collection to include specimens from a wider geographic area will further support fish bone research across the region.
\end{abstract}

\section{Introduction}

Coastal archaeological sites in tropical Australasia (particularly shell middens) characteristically contain accumulations of marine faunal remains, such as molluscan shells and animal bones (especially fish, marine mammals and marine reptiles). While the majority of faunal material is molluscan in nature, there is usually also a small percentage of fish bone, which has the potential to significantly inform discussions regarding human foraging choices and environmental change. Despite the importance of fish remains, with the exception of western Torres Strait (e.g. David and Weisler 2006; McNiven et al. 2008), few detailed studies exist for the northern Australasian region owing to the small number of analysts and the availability of appropriate reference collections. Recovery techniques have also significantly impacted on the representation of fish bone from archaeological deposits. Walters (1979) found that as much as $80 \%$ of fish remains passed through $3 \mathrm{~mm}$ mesh (based on analysis of a single 661.6g bulk sample). Walters' study also demonstrated that the use of larger mesh sizes biased recovery against some fish taxa with small diagnostic skeletal elements, such as mullet and whiting.

Analysis of an archaeo-ichthyological assemblage generally begins with identification and quantification of the materials. Fish remains are commonly identified according to skeletal element and taxon (family, genus and species) and involves comparing morphological features with those of extant specimens (Ellis 2000:16). However, access to suitable reference materials can be problematic, particularly as there are only a few fish bone reference collections housed in Australia that have been created for archaeological purposes (e.g. collections at The University of Queensland Archaeological Science Laboratories, established by Marshall Weisler, and the Australian National University (ANU) Archaeology and Natural History Department, established by Gary Barnett) (ANU 2009). The Archaeological Fish-Bone Images Database (AFBI database), a recent initiative of Sarah Colley and The University of Sydney Library, provides remote access to a selection of The University of Sydney and ANU Archaeology and Natural History fish osteological collections (Colley and Brownlee 2010). The platform enables users to view photographs of fish bones contained in the reference collections. At present there are only a few images of selected anatomical elements available for each species, and unfortunately otoliths (the most diagnostic elements of all) are absent. As more images are added to the database its value to scientists as a research tool will continue to grow.

Despite the excellent quality of these collections, not all regions have equal representation owing to the immense species richness of Australian waters spread across both temperate and tropical zones. Ongoing research in the Wellesley Islands in the southern Gulf of Carpentaria (e.g. Ulm et al. 2010) highlighted a shortfall of suitable reference specimens from that region and we found it necessary to develop a new osteological collection of extant Gulf of Carpentaria fish species. Over 150 fish species are reported for the Wellesley Islands area, representing at least 50 recorded families and conceivably hundreds more for all Gulf of Carpentaria waters (Johnson and Gill 2005; Malcolm 1998).

This paper outlines the methods adopted for creating the osteological collection, which at present contains bones from 52 fish representing 35 different species found in Gulf of Carpentaria waters. Table 1 lists all species presently contained in the Tropical Archaeology Research Laboratory (TARL) Comparative Fish Reference Collection. As well as being a valuable physical resource tool for analysts working in north Queensland, the collection has potential to supplement the AFBI database (Colley and Brownlee 2010) and support fish bone research in other tropical regions.

\section{Methods}

\section{Procurement}

An appropriate and useful reference collection should ideally comprise disarticulated skeletons from many different fish species or at least representation from different fish families. It is also advisable to have specimens of different sizes from each species, which are useful for size reconstruction studies. When collecting specimens various laws and regulations of nature conservation and natural resources management policies must be observed and ethical issues concerning collection of live specimens must be considered (Plug 1991:19). 
The majority of fish specimens selected for inclusion in the collection were caught for food by Kaiadilt Aboriginal traditional owners and the authors. Fishing was carried out using handlines in most cases, although occasionally nets and fishing rods were also used. All fishers engaged in the project were asked to take particular care with each specimen during capture, and requested to contact the authors as soon as possible when bringing the catch ashore. In addition, several specimens sourced to the Gulf of Carpentaria were purchased from commercial fish shops to supplement the collection (Appendix A).

\section{Preparation}

There are a number of different techniques of skeletal preparation including maceration (natural process of rotting involving bacteria and elevated temperatures), the use of enzymes (which decompose the flesh), or cooking followed by picking bones out of the flesh (Casteel 1976; Colley and Spennemann 1987; Ellis 2000). We used a combination of methods because of the limited processing time available. Because the comparative material would frequently be handled it was also necessary to ensure the specimens were clean and hygienic (Plug 1991). Cleaning methods vary and little is known about their long-term effects on specimens; the findings of some known studies are reviewed in the discussion section below. The remainder of this section is presented as a step-by-step guide to specimen preparation.

\section{Step 1}

- Identify each fish specimen to family, genus and species, using photographs in reference books (e.g. Andrawartha and Tuma 2007; Grant 1993, Prokop 2002). Confirm current taxonomic names of all specimens with the World Register of Marine Species (Appletans et al. 2012).

- Consult with traditional owners about Indigenous language names for fish specimen.

- Allocate each specimen a unique reference number and photograph with a scale as soon as possible after capture.

- Take measurements of the fish while still whole including total length, standard length, fork length, head length, depth (see Figure 1) and fresh (unfrozen) weight (Froese and Pauly 2012).

- Record this information on a standardised data collection form (e.g. Appendix B), along with other information such as method of capture, name of the collector, date of collection and locality description of where the fish was caught, including a Global Positioning Reading, if available.

\section{Step 2 (Optional)}

- The fish can be gutted and carefully prepared for cooking (e.g. filleted or cooked whole and carefully picked of meat, leaving the head and carcass intact).

- $\quad$ Place entire fish skeleton in a sealed plastic bag labelled with catalogue number and keep in the freezer until required for processing.

- Include a tag with the catalogue number in a small zip lock bag inside the specimen bag.

\section{Step 3}

- $\quad$ Bring a large stockpot (three-quarters full of water) to the boil. We used a range of different-sized pots for different-sized fish (i.e. 5L, 10L, 20L).

- $\quad$ Turn boiling water down to a simmer before placing the fish in the pot using tongs (if the fish is too large for the pot, carefully cut it in half between two vertebrae to fit) (Figure 2).

- $\quad$ Once any remaining flesh starts to come easily away from the bones, remove pot from heat source and allow water to cool slightly.

- Pour pot contents through a fine-meshed sieve (1mm) or colander into a bucket (taking care not to lose any bones that may have loosened from the skeleton).

- $\quad$ Discard the water.

\section{Step 4}

- Remove as much flesh from the bones as possible by hand, wearing gloves if necessary (place bones in sieve or colander and flesh in second bucket) (Figure 3).

- Carefully disarticulate the skeleton into individual bones or diagnostic elements (e.g. cranial, scales, scutes, vertebrae; please refer to the discussion under cataloguing below). Note how elements fit together before the fish is completely disarticulated. It is helpful to take a photograph of the defleshed but still articulated skeleton for later reference during element identification stage.

- Check through the flesh a second time for small bones.

- Once confident that all bones are accounted for, the flesh can be discarded. It can be useful to lay out all the specimens in anatomical order to make sure there are the correct numbers of elements and/or lay the elements out on a line drawing of a fish skeleton.

\section{Step 5}

- Fill a container (e.g. large ice-cream container with lid) three-quarters full with warm water (not too hot, just so you can still put your hand in).

- Dissolve manufacturer-recommended quantity of enzyme-containing laundry detergent in water - we found that Vanish Napisan Oxi Action Powder ${ }^{\circledR}$ (marketed by Reckitt Benckiser) works effectively for removing flesh and grease from the bones (however, see discussion below regarding potential effects on specimens).

- Immerse bones in the solution and loosely place lid on container (do not seal as air needs to escape during reaction). Store in an area protected from weather, animals and insects.

- There is no set time for leaving the bones in the container as the results are dependent on the size of fish bones and ambient temperature of the water (smaller more fragile bones clean more quickly than larger more robust bones, and similarly warm temperatures have a more rapid effect than cooler temperatures). 
Table 1. Fish species represented in the TARL Comparative Fish Reference Collection.

\begin{tabular}{|c|c|c|c|c|}
\hline Family & Genus & Species & Common Name & No. of Specimens \\
\hline Ariidae & Neoarius & graeffei & Blue Catfish & 1 \\
\hline Belonidae & Tylosurus & gavialoides & Stout Longtom & 2 \\
\hline Carangidae & Caranx & bucculentus & Bluespotted Trevally & 1 \\
\hline Carangidae & Caranx & ignobilis & Giant Trevally & 1 \\
\hline Carangidae & Caranx & papuensis & Brassy Trevally & 1 \\
\hline Carangidae & Scomberoides & commersonnianus & Giant Queenfish & 3 \\
\hline Carcharhinidae & Carcharhinus & amblyrhynchos & Grey Reef Shark* & 1 \\
\hline Carcharhinidae & Carcharhinus & melanopterus & Blacktip Reef Shark* & 1 \\
\hline Elopidae & Elops & machnata & Australian Giant Herring & 1 \\
\hline Gerridae & Gerres & subfasciatus & Common Silverbiddy & 2 \\
\hline Haemulidae & Pomadasys & kaakan & Barred Javelin & 2 \\
\hline Hemiramphidae & Arrhamphus & sclerolepsis & Snubnose Garfish & 1 \\
\hline Labridae & Choerodon & cyanodus & Blue Tuskfish & 1 \\
\hline Labridae & Choerodon & schoenleinii & Blackspot Tuskfish & 1 \\
\hline Latidae & Lates & calcarifer & Barramundi & 1 \\
\hline Lethrinidae & Lethrinus & laticaudis & Grass Emperor & 3 \\
\hline Lutjanidae & Lutjanus & carponotatus & Stripey Snapper & 3 \\
\hline Lutjanidae & Lutjanus & johnii & Golden Snapper & 3 \\
\hline Lutjanidae & Lutjanus & russellii & Moses’ Snapper & 1 \\
\hline Lutjanidae & Lutjanus & sebae & Red Emperor & 1 \\
\hline Mugilidae & Liza & vaigiensis & Diamondscale Mullet & 2 \\
\hline Mugilidae & Mugil & cephalus & Sea Mullet & 1 \\
\hline Platycephalidae & Platycephalus & arenarius & Northern Sand Flathead & 1 \\
\hline Polynemidae & Polydactylus & macrochir & King Threadfin & 1 \\
\hline Rachycentridae & Rachycentron & canadum & Cobia Black Kingfish & 1 \\
\hline Scombridae & Scomberomorus & commerson & Spanish Mackerel & 1 \\
\hline Serranidae & Epinephelus & coioides & Goldspotted Rockcod & 4 \\
\hline Serranidae & Epinephelus & malabaricus & Blackspotted Rockcod & 1 \\
\hline Serranidae & Plectropomus & leopardus & Common Coral Trout & 2 \\
\hline Serranidae & Plectropomus & maculatus & Barcheek Coral Trout & 1 \\
\hline Sillaginidae & Sillago & burrus & Western Trumpeter Whiting & 2 \\
\hline Sparidae & Acanthopagrus & berda & Pikey Bream & 1 \\
\hline Sparidae & Acanthopagrus & latus & Western Yellowfin Bream & 1 \\
\hline Sphyraenidae & Sphyraena & barracuda & Great Barracuda & 1 \\
\hline Terapontidae & Amniataba & caudovittata & Yellowtail Grunter & 1 \\
\hline
\end{tabular}

* Only vertebrae survived the preparation process due to the cartilaginous nature of shark skeletons.

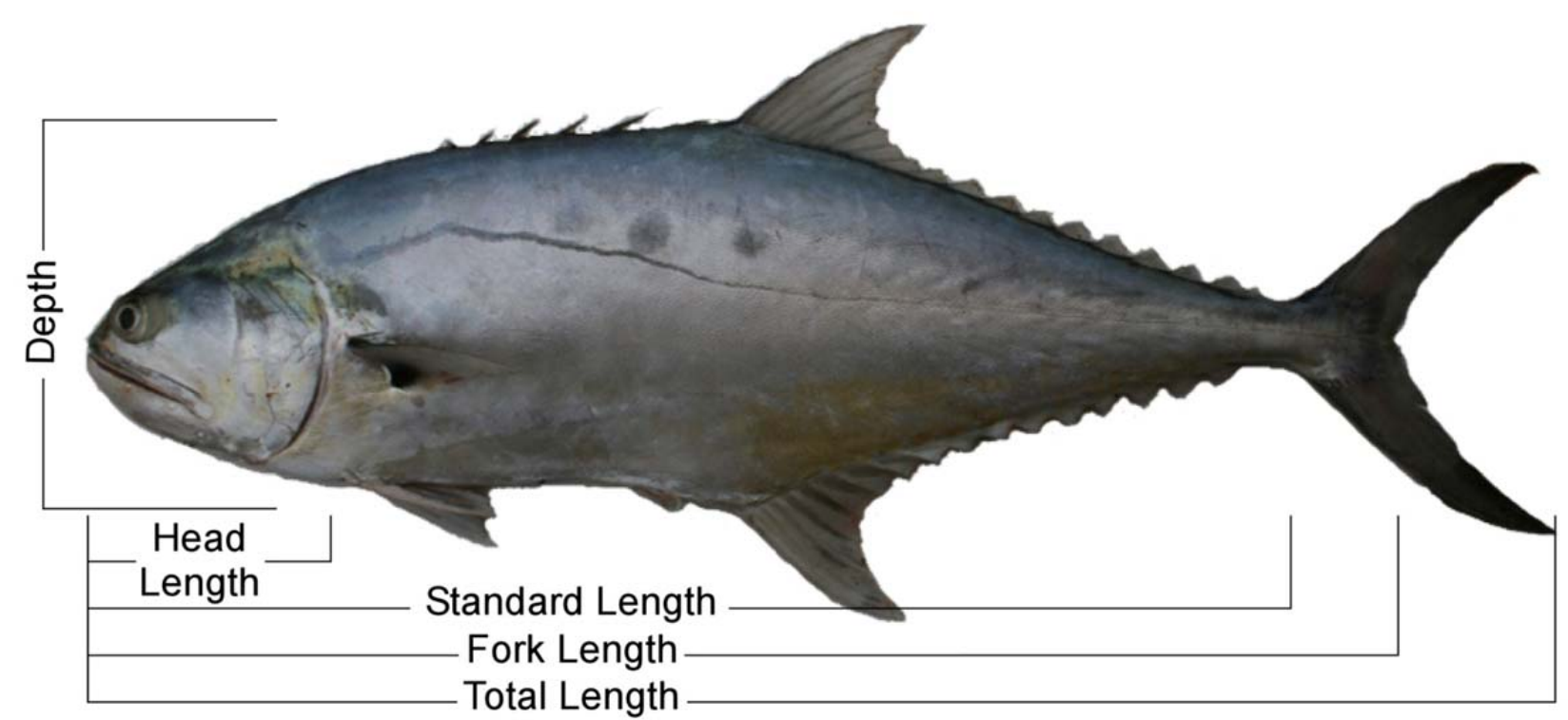

Figure 1. Standard fish measurements as described in Step 1. 


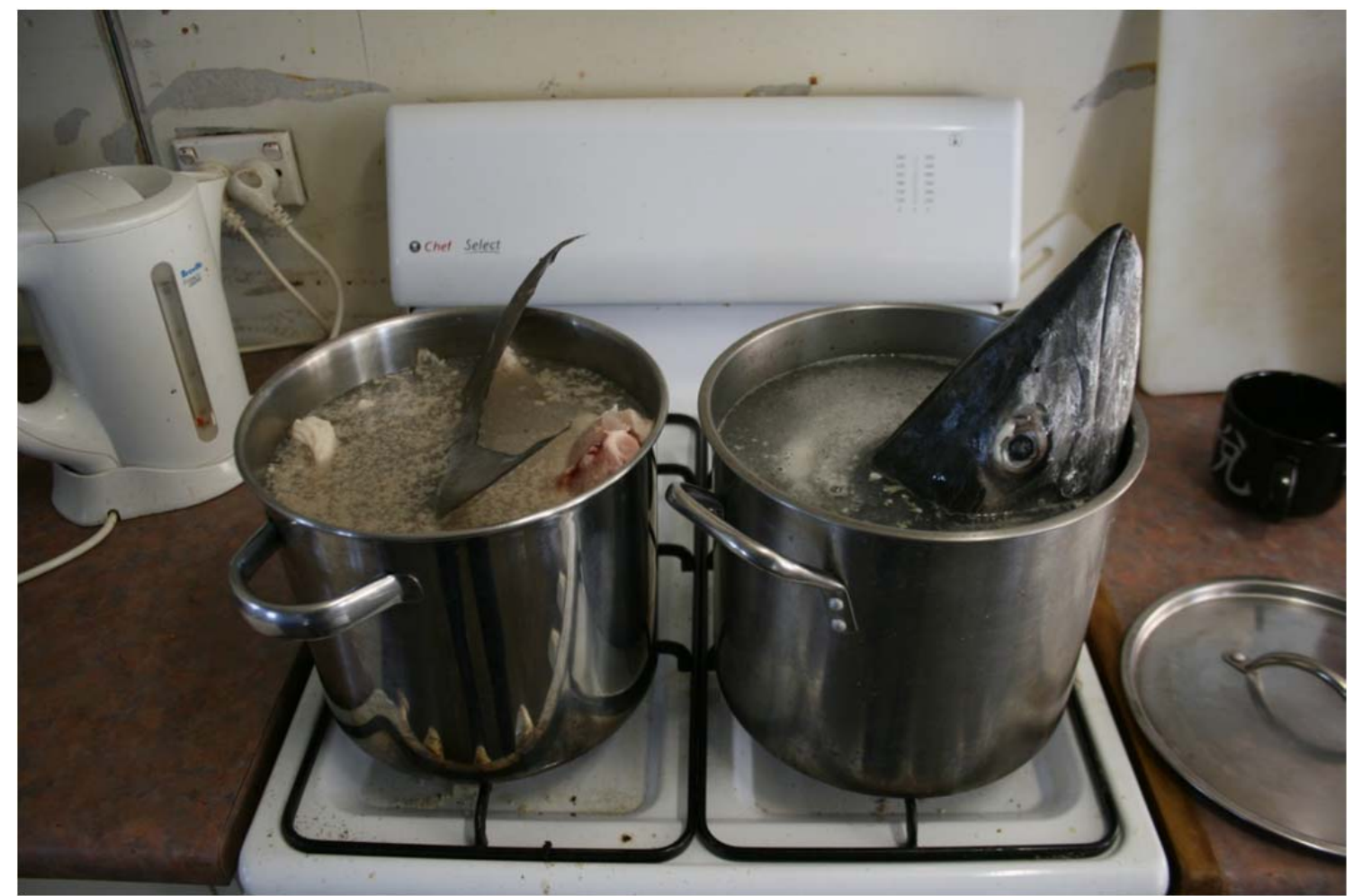

Figure 2. Boil fish to loosen flesh from bones as described in Step 3.

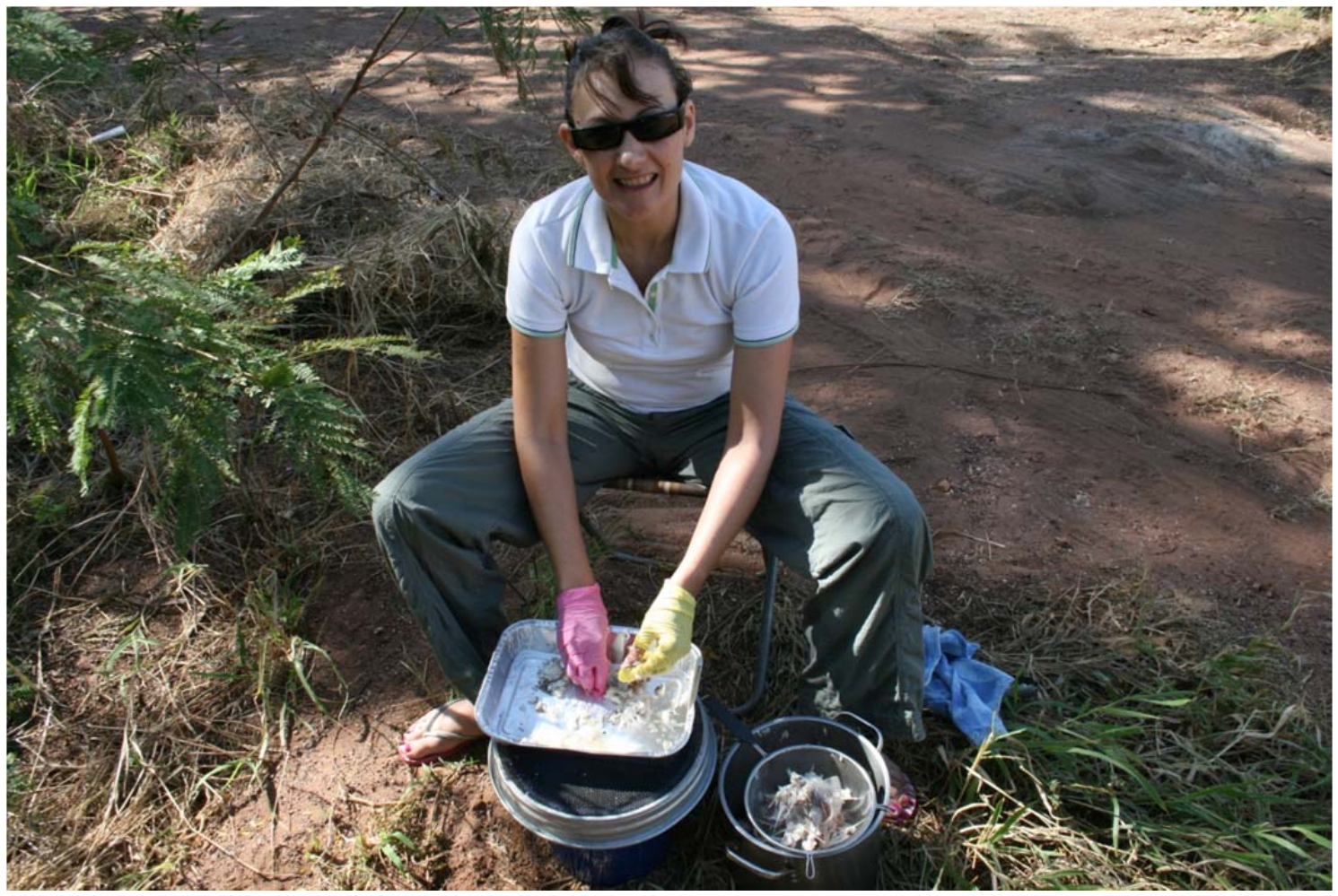

Figure 3. Remove flesh from fish skeleton and disarticulate as described in Step 4. 
- Check the bones in solution every 24 hours to monitor progress (sometimes this is all the time needed to sufficiently clean the bones). Note that excessive soaking of the bones in solution may lead to pitting damage to bone elements.

- $\quad$ Remove the bones from water, pouring through a fine mesh sieve (1mm) so as not to lose any elements.

- $\quad$ Discard water.

\section{Step 6}

- Thoroughly rinse the bones in freshwater several times to ensure the washing solution is removed from the bones (see below for effects on specimens).

- $\quad$ Place bones on a drying tray and place in a protected area for about a week or until the bones are completely dry. Include a label on the tray with the specimen number, name of specimen and date.

- Transfer to storage container and label with relevant catalogue number (we use plastic airtight containers for this task).

\section{Cataloguing}

A fish typically contains up to 300 bones and other skeletal parts; some (but not all) are diagnostic to taxon. Key jaw bones such as dentary, articular, maxilla and premaxilla (Figure 4) are highly diagnostic to species for a wide range of fish taxa (Leach 1986), as are otoliths (Weisler 1993). Other skeletal parts are also variably diagnostic for particular taxa (Vogel 2005), including various head bones, scales, scutes and vertebrae (see also Casteel 1976; Leach 1986). We selected up to 17 diagnostic elements from each specimen and labelled them directly on the bones with catalogue numbers using a waterproof, carbon-based permanent ink pen. If you know which side of the fish the element is from (left or right) this can be written on as well (e.g. 36L would be written on a 'left dentary' from a specimen with reference number 36). Use of schematic reference diagrams (e.g. Casteel 1976; Colley 1990; Starks 1901; Wheeler and Jones 1989) facilitated identifying individual elements (it may also be necessary to refer back to the photograph taken in Step 4 of the preparation methods). This stage can be quite a time-consuming task, but if the skeletal elements are actively used then this task is critical in order to ensure all bones are not mixed up with other specimens. Figures 4-5 show all the elements we have isolated and labelled to date.

\section{Storage, Curation and Use}

Two methods of storage are used for this collection; by diagnostic element and by taxon. Once labelled, individual diagnostic cranial elements from each fish (Figure 4) are removed from the remainder of the skeleton and stored in commercially available plastic boxes divided into several compartments. These elements are grouped together by element type and side (e.g. all 'left dentary' bones are stored in the same compartment, all 'right post-temporal' bones are stored in the same compartment) (Figure 6). All remaining bones from each fish are stored in larger plastic boxes (e.g. airtight takeaway containers), with one fish in each box. We have found this to be the most convenient way to store the collection for ease of referral and use as a comparative identification tool. It is important to ensure that the containers are stored away from direct sunlight as over time plastic containers become brittle and crack. It can help to include a small sachet of desiccant with the specimens to absorb moisture. This dessicant needs to be replaced periodically.

Maintenance of the collection has generally been low, with the main task being relabeling of diagnostic elements. Although permanent-ink was used for labeling, some of the bones were initially still coated with grease that caused ink not to adhere properly. Continued handling of the elements has also caused ink to occasionally rub off, so regular checking and relabeling is recommended. The most arduous task of maintenance has been remedial processing work to remove excess grease and occasional cases of mould growth on some bones. Unfortunately we also found that a small percentage of the bones in the collection, mainly those from small specimens, are showing signs of brittleness and pitting. Investigations into the possible causes indicate a flaw in the initial processing procedures adopted (see below).

At present the collection is used primarily as a direct physical reference tool for identifying archaeological fish bone remains based on comparing the morphological characteristics of bone remains with our known-taxa diagnostic specimens. In time, as more information is collected and recorded for specimens in the collection, it could potentially be used for size reconstruction and seasonality studies (Casteel 1976; Colley 1990). To facilitate reconstruction studies, measurements of selected bones in the collection could be recorded and analysis performed to obtain regression equations that demonstrate the relationship between bone size and fish length (e.g. Gabriel et al. 2012; Harvey et al. 2000; Zohar et al. 1997). Photographs of bone elements from selected species could either be incorporated into the AFBI or otherwise be made available electronically for remote access by other analysts.

An important part of the project has been using the data collected in developing the TARL Fish Reference Collection to produce language resources for the Kaiadilt and Lardil Aboriginal communities in the Gulf of Carpentaria (e.g. Figure 7).

\section{Discussion}

A great deal of time is invested in making an osteological reference collection so caring for it should be paramount. Climate conditions, such as humidity, can have a detrimental effect on the condition of bones and careful storage is necessary to prevent build-up of mould on bones. In order to stave off mould and insects some analysts prepare specimens by immersing bones in a diluted hydrogen peroxide solution, however bleaching has been reported to harm bones (e.g. Williams 2005).

Enzyme detergents are also reported to work well for degreasing skeletons of birds and mammals, however some studies have found that they do not always perform as well with fish and have resulted in the destruction of fish bones (Mayden and Wiley 1984; Ossian 1970; Williams 2005). Shelton and Buckley (1990:77) report that problems can occur because enzymes are not specifically known, not used at controlled concentrations and durations, and most importantly not denatured or neutralised after treatment. 


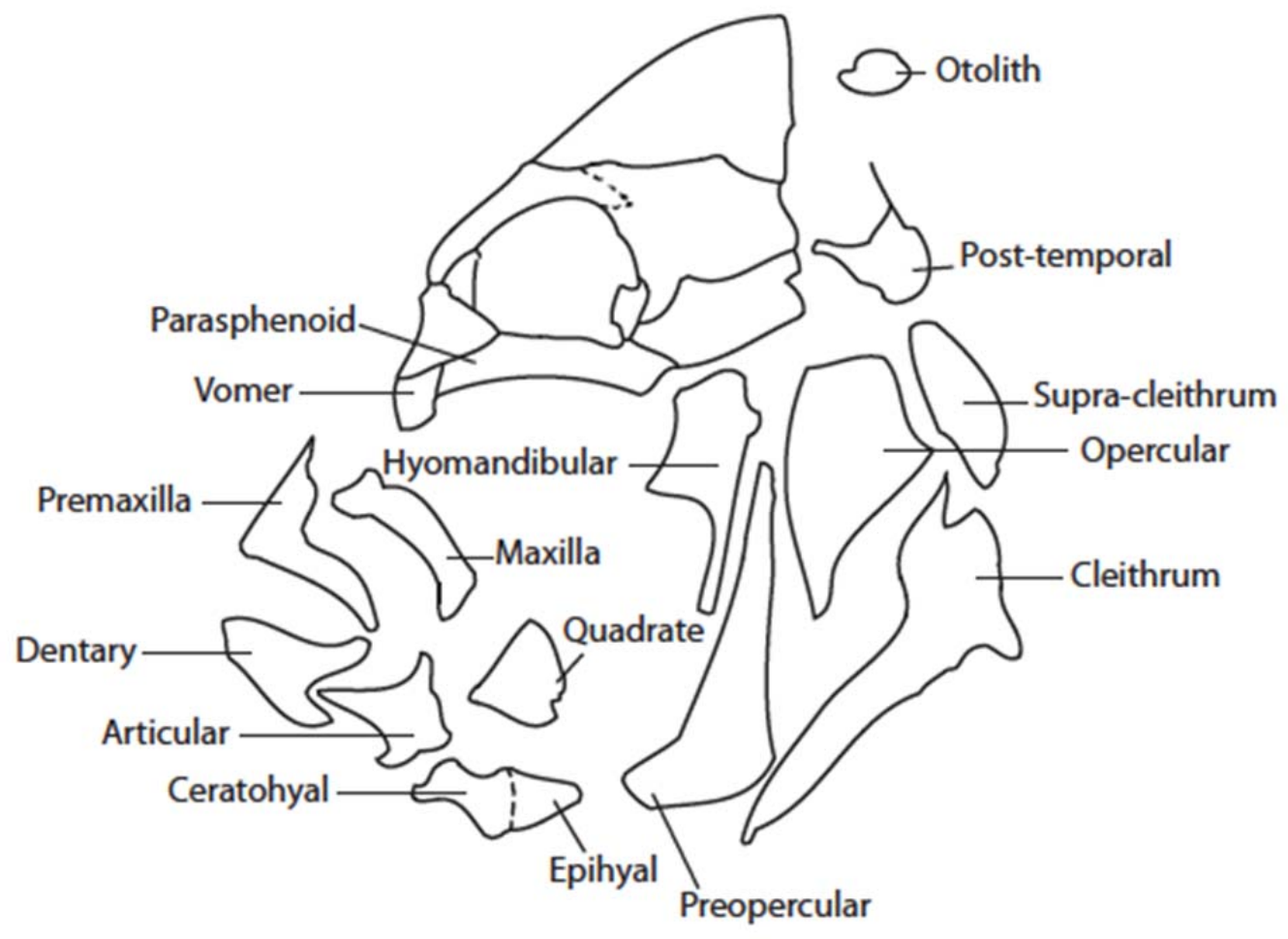

Figure 4. Schematic diagram of fish head showing skeletal elements isolated and labelled for the TARL Collection (after Mumford in Colley 1990:213).

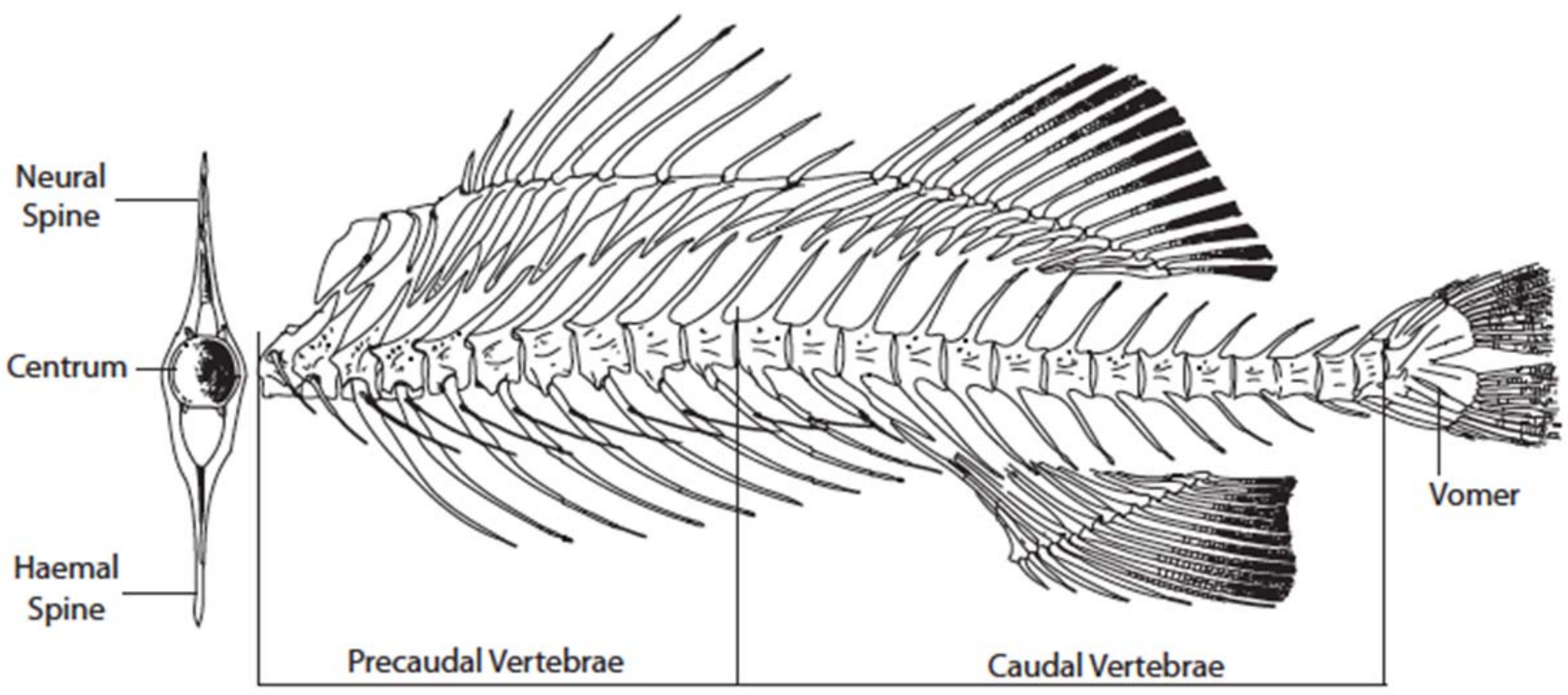

Figure 5. Schematic diagram of fish post-cranial skeleton showing additional skeletal parts labelled for the TARL Collection (after Starks 1901:Plate LXV). 


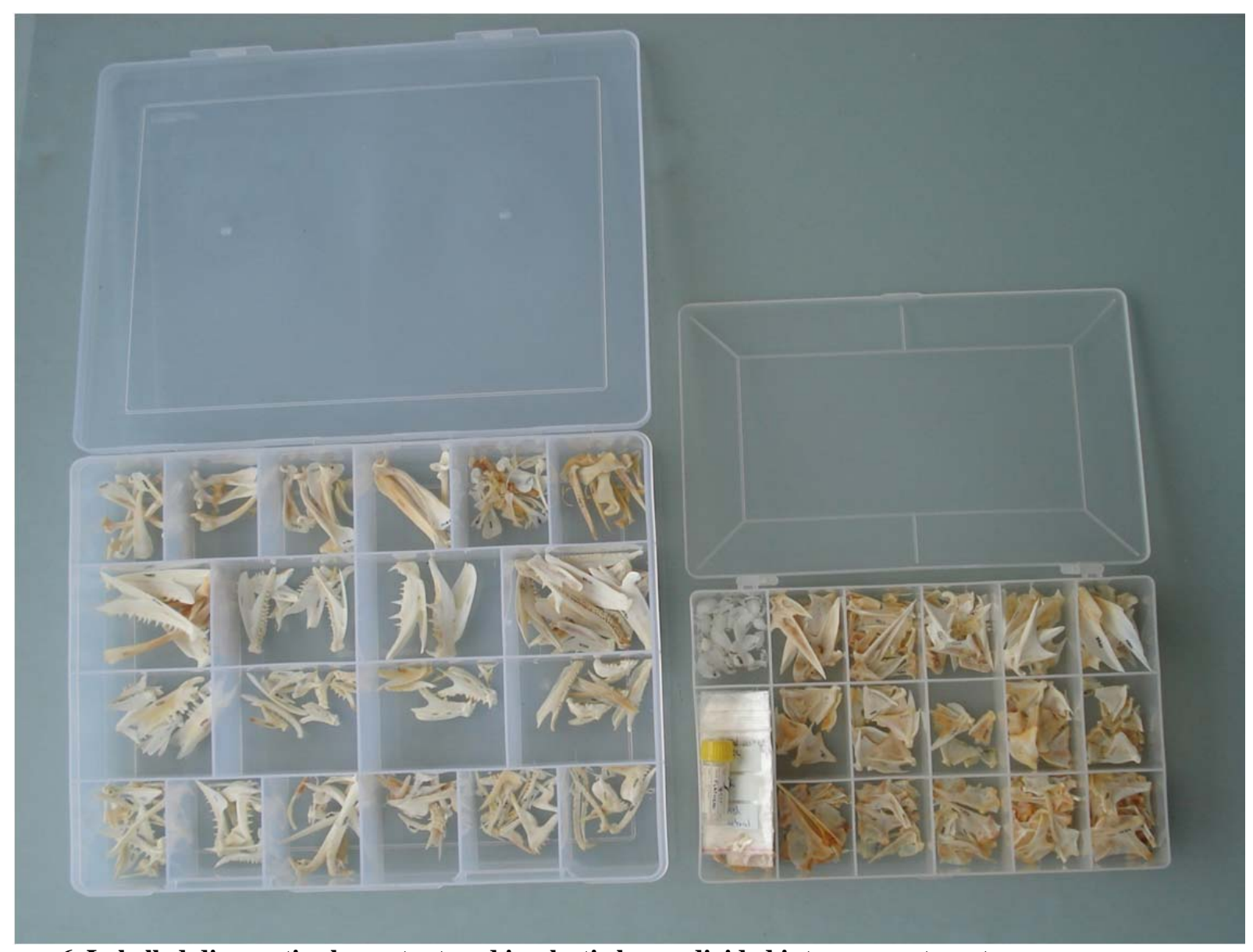

Figure 6. Labelled diagnostic elements stored in plastic boxes divided into compartments.

The main problem encountered to date with our collection is with the preservation of some bones in the collection. As mentioned previously, some early specimens added to the collection (2-3 years ago) are showing signs of deterioration such as pitting and brittleness. This problem has been reported by other analysts who access similar collections and can be traced back to initial preparation methods (Shelton and Buckley 1990). We found that the issue is most often due to problems with stabilisation of the enzymes and/or cleaning reaction, in particular halting the deterioration effects on specimens.

We used a commercially available laundry detergent Vanish Napisan Oxi Action Powder ${ }^{\circledR}$ (marketed by Reckitt Benckiser) to remove flesh from the bones. This product contains oxygen-based bleach ingredients sodium carbonate and disodium carbonate compound with hydrogen peroxide 2:3. Vanish Napisan Oxi Action Powder ${ }^{\circledR}$ also contains stain-release enzymes that actively break protein and fat bonds, which aid with decomposing flesh. Vanish Napisan Sensitive Powder ${ }^{\circledR}$ is a similar product to the Vanish Napisan Oxi Action Powder ${ }^{\circledR}$ but it does not contain enzymes. We have also trialled this product and have found it to be just as effective with less side-effects, however it does require longer periods for soaking fish carcasses in solution. Ultimately, caution should be exercised when using any enzyme-based or bleaching preparation method and it is very important to thoroughly rinse bones well after immersion in any product.

\section{Conclusion}

Analysts adopt different methods when preparing reference collections and each approach has advantages and disadvantages. Under ordinary circumstances, specimens can be prepared without using costly chemicals. In the field we found that a process that combines boiling followed by soaking in an enzymebased laundry pre-soaker to be the most convenient and efficient method. Costs were kept to a minimum in this situation with equipment and materials sourced from everyday household products. Fish specimens procured were in most cases free as we caught and ate them first. The major investment was labour to process, catalogue and prepare specimens for storage. Analysts who use such collections note their inherent benefits as a research tool for informing discussions regarding human subsistence and interactions with their environment.

\section{Acknowledgements}

The project on which this paper is based was supported under Australian Research Council's Discovery Projects funding scheme (project numbers DP0663047 and DP120103179). Sean Ulm is the recipient of an Australian Research Council Future Fellowship (project number FT120100656). We acknowledge the Kaiadilt, Lardil, Yangkaal and Gangalidda traditional owners of the Wellesley Islands as partners in this research project. The Gulf Region Aboriginal Corporation RNTBC collaborated in establishing the research framework for this project. Thanks to Brit Asmussen and Bryce Barker for comments on the manuscript. Annette Oertle reproduced the fish skeleton figures. Thanks to Sarah Colley for allowing 


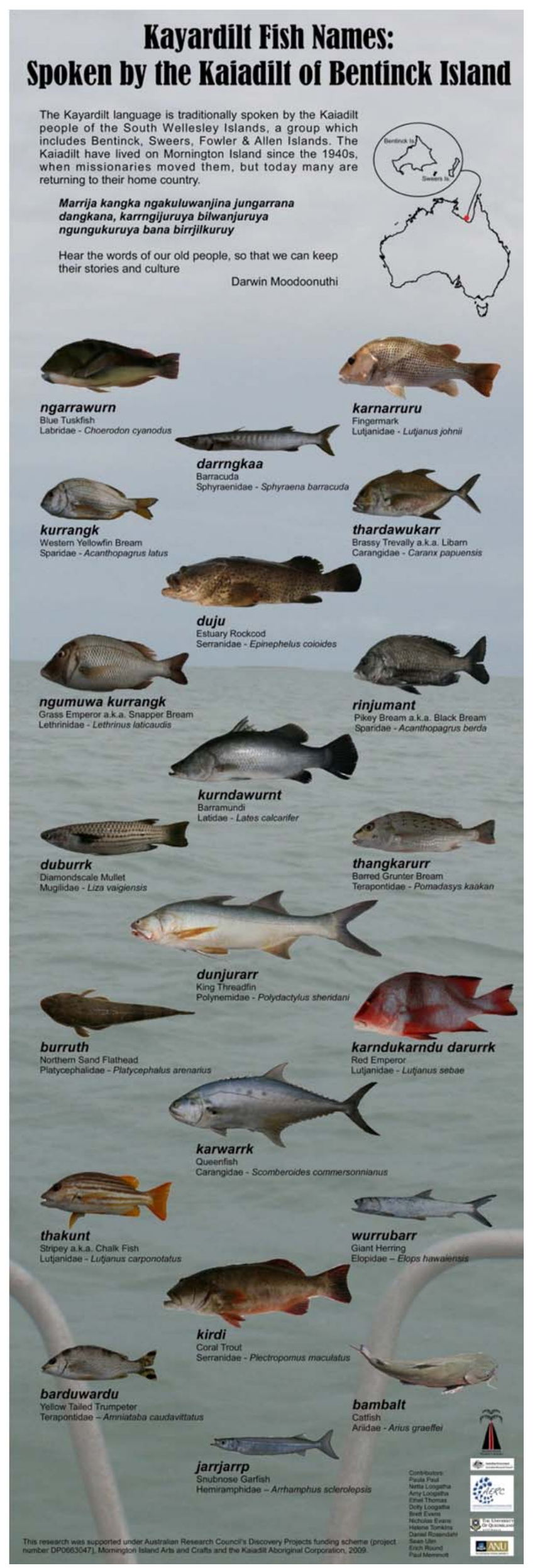

Figure 7. Kayardilt fish names: A poster produced in collaboration with the Kaiadilt community (Paul et al. 2009). A similar poster was produced for Lardil speakers. 
Reproduction of Figure 4. Mick Davies and Tex Battle of Sweers Island Resort supplied fishing gear, offered advice about fishing locations and provided specimens for the collection. We thank Paula Paul, Netta Loogatha, Amy Loogatha, Ethel Thomas, Dolly Loogatha and Duncan Kelly for allowing access to their country and also providing the remnants of their fish meals for the collection. Sam Aird, Nicholas Evans, Lydia Mackenzie, Patrick Moss, Texas Nagel, Annette Oertle, Emma Oliver, Lynda Petherick, Jill Reid, Craig Sloss, Lincoln Steinberger, Alison Sternes and Rene Simpson are all thanked for their comradeship, fishing prowess and, of course, providing good-eating fish that eventually ended up in the collection.

\section{References}

Andrawartha, B. and D. Tuma 2007 Fil-O-Fish Australia: Recreational and Commercial Fish Handbook. Balnarring, VIC: Candlelight Publishing.

Appeltans, W., P. Bouchet, G.A. Boxshall, C. De Broyer, N.J. de Voogd, D.P. Gordon, B.W. Hoeksema, T. Horton, M. Kennedy, J. Mees, G.C.B. Poore, G. Read, S. Stöhr, T.C. Walter and M.J. Costello (eds) 2012 World Register of Marine Species. Retrieved 4 December 2012 from http://www.marinespecies.org.

Australian National University 2009 ANU Archaeology and Natural History Osteological Reference Collection. Retrieved $\quad 13 \quad$ November 2012 from http://rspas.anu.edu.au/anh/osteology.

Casteel, R.W. 1976 Fish Remains in Archaeology and Paleoenvironmental Studies. London: Academic Press.

Colley, S. 1990 The analysis and interpretation of archaeological fish remains. In M.B. Schiffer (ed.), Archaeological Method and Theory 2, pp.207-253. Tuscon: University of Arizona Press.

Colley, S. and R. Brownlee 2010 Archaeological Fish Bones Online: A digital archive of Sydney fishes. Internet Archaeology 29. Retrieved 10 November 2012 from http://intarch.ac.uk/journal/issue29/colley_index.html.

Colley, S.M. and D.H.R. Spennemann 1987 Some methods of preparing fish skeletons in the tropics. Journal of Field Archaeology 14:117-120.

David, B. and M.I. Weisler 2006 Kurturniaiwak (Badu) and the archaeology of villages in Torres Strait. Australian Archaeology 63:21-34.

Ellis, L. 2000 Archaeological Methods and Theory: An Encyclopedia. New York: Garland Publishing.

Froese, R. and D. Pauly (eds) 2012 FishBase. Retrieved 10 December 2012 from http://www.fishbase.org/search.php.

Gabriel, S., N. Prista and M.J. Costa 2012 Estimating meagre (Argyrosomus regius) size from otoliths and vertebrae. Journal of Archaeological Science 39:2859-2865.

Grant, E. 1993 Grant's Guide to Fishes. Scarborough: E.M. Grant Pty Limited.

Harvey, J.T., T.R. Loughlin, M.A. Perez and D.S. Oxman 2000 Relationship between Fish Size and Otolith Length for 63 Species of Fishes from the Eastern North Pacific Ocean. NOAA Technical Report NMFS 150. Seattle: Fishery Bulletin US Department of Commerce.

Johnson, J.W. and A.C. Gill 2005 Reef and shore fishes of Sweers Island, Gulf of Carpentaria. In Gulf of Carpentaria Scientific Study Report, pp.239-260. Geography Monograph Series 10. Brisbane: The Royal Geographical Society of Queensland Inc.
Leach, B.F. 1986 A method for analysis of Pacific island fishbone assemblages and an associated data base management system. Journal of Archaeological Science 13(2):147-159.

Malcolm, H. 1998 Reef Fish Community and Incidental Observations: Wellesley Islands - Gulf of Carpentaria (October 1997 - May 1998), pp.1-35. A Technical Report to Queensland Department of Environment, Brisbane.

Mayden, R.L. and E.O. Wiley 1984 A method of preparing disarticulated skeletons of small fishes. Copeia 1:230-232.

McNiven, I.J., J. Crouch, M. Weisler, N. Kemp, L.C. Martinez, J. Stanisic, M. Orr, L. Brady, S. Hocknull and W. Boles 2008 Tigershark Rockshelter (Baidamau Mudh): Seascape and settlement reconfigurations on the sacred islet of Pulu, western Zenadh Kes (Torres Strait). Australian Archaeology 66:15-32.

Ossian, C. 1970 Preparation of disarticulated skeletons using enzyme-based laundry “pre-soakers”. Copeia 1970(1):199200.

Paul, P., N. Loogatha, A. Loogatha, E. Thomas, D. Loogatha, B. Evans, N. Evans, H. Tomkins, D. Rosendahl, S. Ulm, E. Round and P. Memmott 2009 Kayardilt Fish Names: Spoken by the Kaiadilt of Bentinck Island. Gununa, QLD: Mirndiyan Gununa Aboriginal Corporation.

Plug, I. 1991 Accession procedures and criteria for acceptance. In E. Henry (ed.), Guide to the Curation of Archaeozoological Collections, pp.19-23. Proceedings of the Curation Workshop, ICAZ 6th International Conference, Washington.

Prokop, F. 2002 Australian Fish Guide. 2nd ed. Croydon South, VIC: Australian Fishing Network.

Shelton, S.Y. and J.S. Buckley 1990 Observations on enzyme preparation effects on skeletal material. Collection Forum 6(2):76-81.

Starks, E.C. 1901 Synonymy of the fish skeleton. Proceedings of the Washington Academy of Science 3:507-539.

Ulm, S., N. Evans, D. Rosendahl, P. Memmott and F. Petchey 2010 Radiocarbon and linguistic dates for occupation of the South Wellesley Islands, northern Australia. Archaeology in Oceania 45(1):39-43.

Vogel, Y. 2005 Ika. Unpublished MA thesis, Anthropology Department, University of Otago, Dunedin.

Walters, I.N. 1979 Information Loss in Zooarchaeology: A Study of Vertebrate Remains from Two Middens, Moreton Island, Queensland. Unpublished B.A. (Hons) thesis, Department of Anthropology and Sociology, University of Queensland, Brisbane.

Weisler, M.I. 1993 The importance of fish otoliths in Pacific Island archaeofaunal analysis. New Zealand Journal of Archaeology 15:131-159.

Wheeler, A. and A.K. Jones 1989 Fishes. Cambridge: Cambridge University Press.

Williams, S. 2005 Appendix T: Curational care of biological collections. In NPS Museum Handbook Part 1: Museum Collections, pp.T1-134. Washington: National Park Service. Retrieved $13 \quad$ November 2012 from http://www.nps.gov/museum/publications/handbook.html.

Zohar, I., T. Dayan, E. Spanier 1997 Predicting grey triggerfish body size from bones. International Journal of Osteoarchaeology 7(2):150-156. 
Appendix A. List of all specimens currently held in the TARL Comparative Fish Reference Collection.

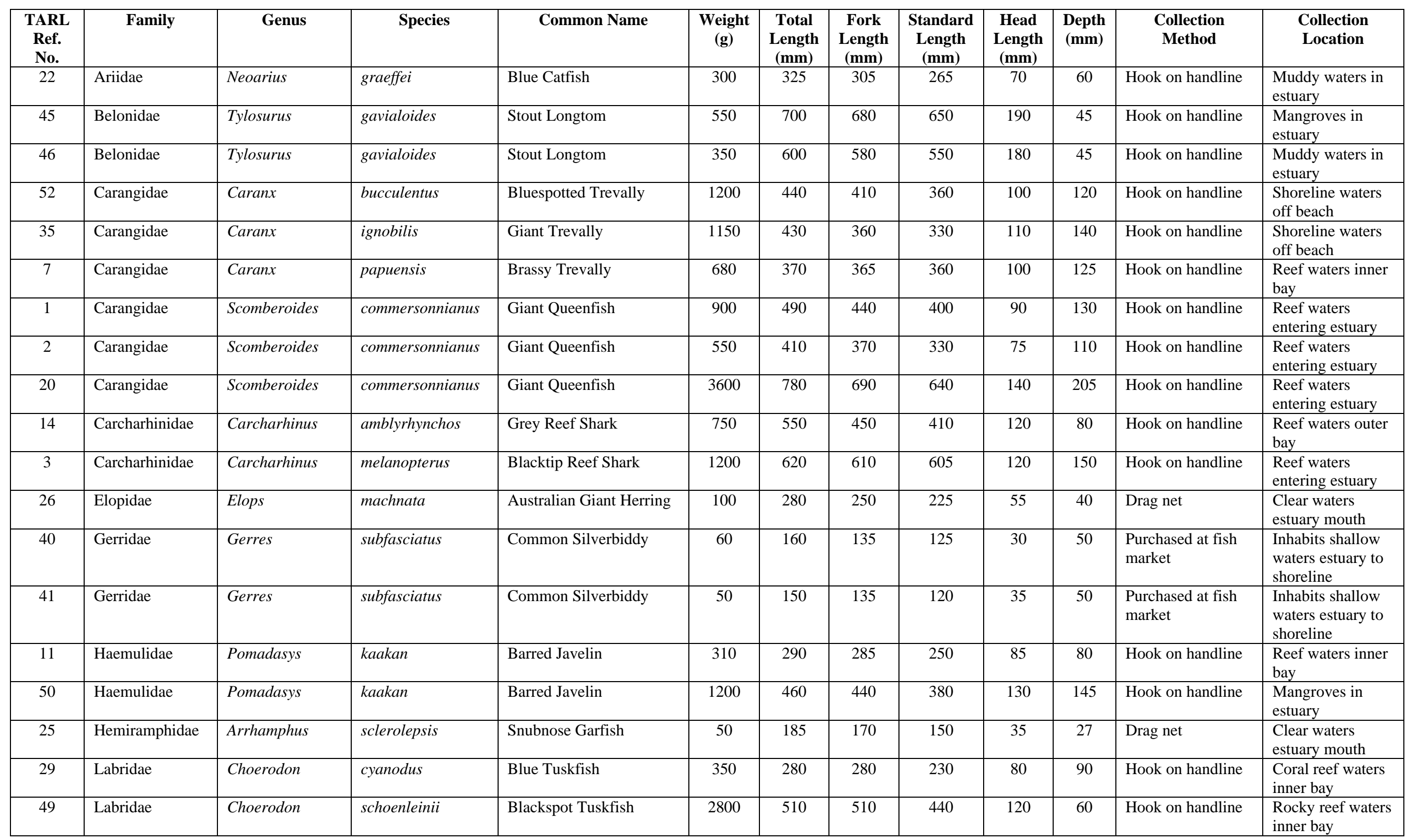




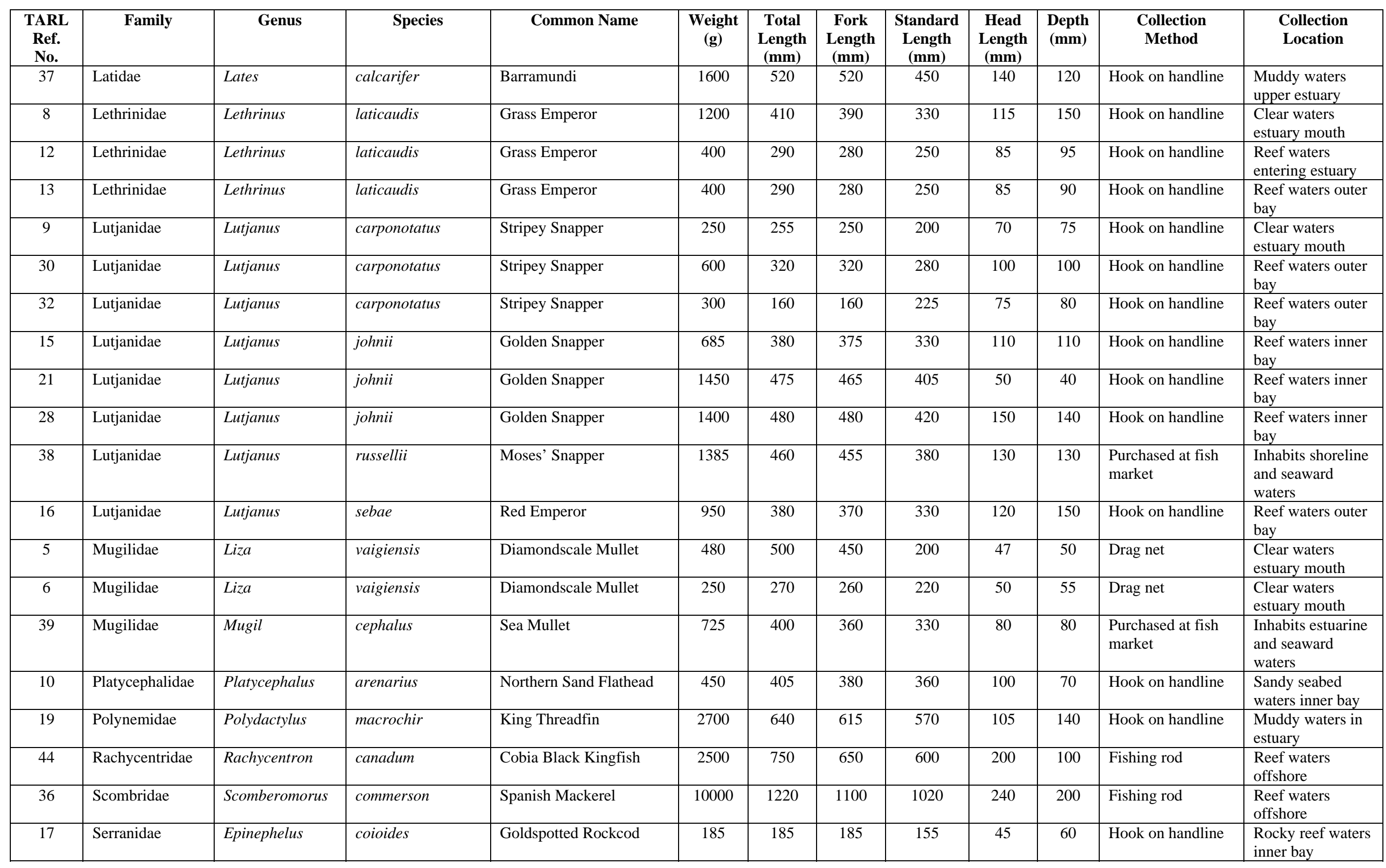




\begin{tabular}{|c|c|c|c|c|c|c|c|c|c|c|c|c|}
\hline $\begin{array}{l}\text { TARL } \\
\text { Ref. } \\
\text { No. } \\
\end{array}$ & Family & Genus & Species & Common Name & $\begin{array}{l}\text { Weight } \\
\text { (g) }\end{array}$ & $\begin{array}{c}\text { Total } \\
\text { Length } \\
(\mathbf{m m})\end{array}$ & $\begin{array}{c}\begin{array}{c}\text { Fork } \\
\text { Length } \\
(\mathbf{m m})\end{array} \\
\end{array}$ & $\begin{array}{l}\text { Standard } \\
\text { Length } \\
\text { (mm) }\end{array}$ & $\begin{array}{l}\text { Head } \\
\text { Length } \\
(\mathrm{mm})\end{array}$ & $\begin{array}{l}\text { Depth } \\
\text { (mm) }\end{array}$ & $\begin{array}{l}\text { Collection } \\
\text { Method }\end{array}$ & $\begin{array}{l}\text { Collection } \\
\text { Location }\end{array}$ \\
\hline 18 & Serranidae & Epinephelus & coioides & Goldspotted Rockcod & 1850 & 540 & 540 & 450 & 190 & 130 & Hook on handline & $\begin{array}{l}\text { Rocky reef waters } \\
\text { inner bay }\end{array}$ \\
\hline 31 & Serranidae & Epinephelus & coioides & Goldspotted Rockcod & 1000 & 430 & 430 & 370 & 160 & 110 & Hook on handline & $\begin{array}{l}\text { Reef waters outer } \\
\text { bay }\end{array}$ \\
\hline 47 & Serranidae & Epinephelus & coioides & Goldspotted Rockcod & 3850 & 610 & 610 & 530 & 210 & 180 & Hook on handline & $\begin{array}{l}\text { Shoreline waters } \\
\text { off rocks }\end{array}$ \\
\hline 48 & Serranidae & Epinephelus & malabaricus & Blackspotted Rockcod & 3300 & 580 & 580 & 530 & 240 & 150 & Hook on handline & $\begin{array}{l}\text { Rocky reef waters } \\
\text { inner bay }\end{array}$ \\
\hline 27 & Serranidae & Plectropomus & leopardus & Common Coral Trout & 2500 & 570 & 570 & 490 & 150 & 140 & Hook on handline & $\begin{array}{l}\text { Coral reef waters } \\
\text { outer bay }\end{array}$ \\
\hline 33 & Serranidae & Plectropomus & leopardus & Common Coral Trout & 2000 & 540 & 540 & 460 & 150 & 130 & Hook on handline & $\begin{array}{l}\text { Reef waters outer } \\
\text { bay }\end{array}$ \\
\hline 51 & Serranidae & Plectropomus & maculatus & Barcheek Coral Trout & 1500 & 500 & 480 & 400 & 150 & 100 & Fishing rod & $\begin{array}{l}\text { Reef waters inner } \\
\text { bay }\end{array}$ \\
\hline 42 & Sillaginidae & Sillago & burrus & $\begin{array}{l}\text { Western Trumpeter } \\
\text { Whiting }\end{array}$ & 430 & 320 & 300 & 270 & 80 & 60 & $\begin{array}{l}\text { Purchased at fish } \\
\text { market }\end{array}$ & $\begin{array}{l}\text { Inhabits inshore } \\
\text { waters }\end{array}$ \\
\hline 43 & Sillaginidae & Sillago & burrus & $\begin{array}{l}\text { Western Trumpeter } \\
\text { Whiting }\end{array}$ & 380 & 300 & 280 & 250 & 70 & 50 & $\begin{array}{l}\text { Purchased at fish } \\
\text { market }\end{array}$ & $\begin{array}{l}\text { Inhabits inshore } \\
\text { waters }\end{array}$ \\
\hline 23 & Sparidae & Acanthopagrus & berda & Pikey Bream & 450 & 280 & 270 & 235 & 75 & 100 & Hook on handline & $\begin{array}{l}\text { Reef waters } \\
\text { entering estuary }\end{array}$ \\
\hline 4 & Sparidae & Acanthopagrus & latus & $\begin{array}{l}\text { Western Yellowfin } \\
\text { Bream }\end{array}$ & 320 & 260 & 240 & 210 & 70 & 95 & Hook on handline & $\begin{array}{l}\text { Reef waters } \\
\text { entering estuary }\end{array}$ \\
\hline 34 & Sphyraenidae & Sphyraena & barracuda & Great Barracuda & 1000 & 730 & 660 & 630 & 190 & 80 & Hook on handline & $\begin{array}{l}\text { Muddy waters in } \\
\text { estuary }\end{array}$ \\
\hline 24 & Terapontidae & Amniataba & caudovittata & Yellowtail Grunter & 50 & 150 & 140 & 125 & 35 & 40 & Hook on handline & $\begin{array}{l}\text { Reef waters } \\
\text { entering estuary }\end{array}$ \\
\hline
\end{tabular}


Appendix B. TARL Comparative Fish Reference Collection standardised recording form.

FISH SPECIMEN RECORDING SHEET

Date: Time:

\begin{tabular}{|c|c|c|c|c|c|}
\hline SPECIMEN \# & & PHOTO \# & \multicolumn{2}{|c|}{} \\
\hline Weight (gm) & Total Lgth $(\mathrm{mm})$ & Fork Lgth $(\mathrm{mm})$ & $\begin{array}{c}\text { Standard Lgth } \\
(\mathrm{mm})\end{array}$ & Head Lgth $(\mathrm{mm})$ & Depth $(\mathrm{mm})$ \\
\hline & & & & & \\
\hline
\end{tabular}

TAXONOMIC DATA

CAPTURE DATA

\begin{tabular}{|c|c|c|c|}
\hline Family & & Location & \\
\hline Genus & & Habitat & \\
\hline Species & & Wind speed & \\
\hline Common & & Technology & \\
\hline Kaiadilt & & Bait & \\
\hline
\end{tabular}

COMMENTS 
